\title{
Segmentation pathway genes in the Asian citrus psyllid, Diaphorina citri
}

Sherry Miller ${ }^{1,2}$, Teresa D. Shippy ${ }^{1}$, Prashant S Hosmani ${ }^{3}$, Mirella Flores-Gonzalez ${ }^{3}$, Lukas A Mueller $^{3}$, Wayne B Hunter ${ }^{4}$, Susan J Brown ${ }^{1}$, Tom D'elia $^{5}$ and Surya Saha ${ }^{3,6^{*}}$

${ }^{1}$ Division of Biology, Kansas State University, Manhattan, KS 66506

${ }^{2}$ Allen County Community College, Burlingame, KS 66413

${ }^{3}$ Boyce Thompson Institute, Ithaca, NY 14853

${ }^{4}$ USDA-ARS, U.S. Horticultural Research Laboratory, Fort Pierce, FL 34945

${ }^{5}$ Indian River State College, Fort Pierce, FL 34981

${ }^{6}$ Animal and Comparative Biomedical Sciences, University of Arizona, Tucson, AZ 85721

*Corresponding Author

\section{Abstract}

Insects have a segmented body plan that is established during embryogenesis when the anterior-posterior (A-P) axis is divided into repeated units by a cascade of gene expression. The cascade is initiated by protein gradients created by translation of maternally provided mRNAs, localized at the anterior and posterior poles of the embryo. Particular combinations of these proteins activate specific gap genes to divide the embryo into distinct regions along the A-P axis. Gap genes then activate pair-rule genes, which are usually expressed in part of every other segment. The pair-rule genes, in turn, activate expression of segment polarity genes in a portion of each segment. The segmentation genes are generally conserved among insects, although there is considerable variation in how they are deployed. We 
annotated 24 segmentation gene homologs in the Asian citrus psyllid, Diaphorina citri. We identified most of the genes that were expected to be present based on known phylogenetic distribution. Two exceptions were eagle and invected, which are present in at least some hemipterans, but were not identified in D. citri. Many of these genes are likely to be essential for $D$. citri development and thus may be useful targets for pest control methods.

\section{Introduction}

Segmentation is the process by which repeated units of similar groups of cells are created along the anterior-posterior axis of a developing embryo. The molecular mechanisms involved in this process were first elucidated by large scale developmental mutant screens in the insect model Drosophila melanogaster [1-5]. In Drosophila, segmentation begins with cytoplasmic inheritance of mRNAs that are maternally produced and provided to the oocyte. The products of these maternal-effect genes create gradients that define positional information within the embryo and activate a group of genes known as gap genes. Gap genes are expressed in broad, well-defined domains in the early embryo and activate the next set of transcription factors, the pair-rule genes. Pair-rule genes are expressed in every other segment of the developing embryo and together they activate the expression of segment polarity genes which are expressed in every segment of the developing embryo. Comparative studies in diverse arthropod species have shown that some aspects of the segmentation pathway are highly conserved while other aspects have undergone evolutionary change [6]. The hemipteran insects that have been examined seem to employ a particularly divergent method of segmentation. Most strikingly, the pair-rule genes, 
generally considered the most conserved portion of the segmentation pathway among

insects, have lost their pair-rule expression and function and are expressed segmentally in at least some hemipterans [7-9].

We are participating in a community annotation project to annotate the genome of the hemipteran agricultural pest, Diaphorina citri, also known as the Asian citrus psyllid. D. citri is the vector responsible for the spread of Huanglongbing (citrus greening disease) which has devastated the citrus industry. Here we describe the identification and annotation of $D$. citri orthologs of genes identified in Drosophila segmentation. We found and manually annotated 24 homologs of these genes, as well as several related genes. In most cases, the presence or absence of particular genes in D. citri is consistent with expectations based on reports in other insects. However, eagle and invected, two segmentation genes expected to be present, appear to be missing from the $D$. citri 3 genome. Our annotations pave the way for future work aimed at understanding the expression and function of these genes during D. citri segmentation and the identification of essential genes that could be used as insect control targets.

\section{Results and Discussion}

We searched the $D$. citri v3 genome for orthologs of genes known to be involved in segmentation in Drosophila [10] (Table 1). We then used available evidence to manually annotate the genes that were present $[11,12]$ (Table 1-2). Most manual annotations were straightforward and performed using our workflow [see Methods], so only those requiring additional explanation are described in detail here. 
bioRxiv preprint doi: https://doi.org/10.1101/2020.12.24.424320; this version posted December 25, 2020. The copyright holder for this preprint (which was not certified by peer review) is the author/funder, who has granted bioRxiv a license to display the preprint in perpetuity. It is made available under aCC-BY-NC 4.0 International license.

\section{Annotated D. citri segmentation gene orthologs}

\begin{tabular}{|c|c|c|c|c|c|c|c|c|}
\hline \multirow[t]{2}{*}{ Group } & \multirow[t]{2}{*}{ Gene/Isoform } & \multirow[t]{2}{*}{ OGSv3 ID } & \multicolumn{2}{|c|}{ Gene model } & \multicolumn{4}{|c|}{ Evidence supporting annotation } \\
\hline & & & Complete & Partial & Мсот & IsoSeq & RNASeq & Ortholog \\
\hline \multicolumn{9}{|c|}{ Maternal } \\
\hline & caudal & Dcitro6g04620.1.4 & $x$ & & $x$ & $x$ & & \\
\hline & dorsal & Deitr02g07710.1.1 & $x$ & & $x$ & $x$ & $x$ & $x$ \\
\hline & nanos & Dcitroog11810.1.1 & & $x$ & $x$ & & & $x$ \\
\hline & TGFalpha & Dcitro6g02470.1.1 & $x$ & & $x$ & $x$ & & \\
\hline \multicolumn{9}{|l|}{ Gap } \\
\hline & tailless & Dcitro1g16840.1.1 & $x$ & & & & & $x$ \\
\hline & knirps related 1 & Dcitr10g03830.1.1 & $x$ & & & $x$ & $x$ & $x$ \\
\hline & knirps related 2 & Dcitr10g03860.1.1 & $x$ & & $x$ & & & $x$ \\
\hline & Kruppel国 & & $x$ & & $x$ & & & \\
\hline & hunchback & Deitro9g01780.1.1 & $x$ & & & $x$ & $x$ & \\
\hline & huckebein & Dcitr04g11170.1.1 & $x$ & & $x$ & & $x$ & \\
\hline & orthodenticle & Dcitr04g16960.1.1 & $x$ & & $x$ & & $x$ & $x$ \\
\hline & emptyspiracles & Dcitro9g06330.1.1 & $x$ & & $x$ & & & \\
\hline & cap-n-collar & Dcitr03g12850.1.1 & $x$ & & $x$ & & & \\
\hline & collier & $\begin{array}{l}\text { Dcitr03g01400.1.1 } \\
\ldots \ldots \ldots \ldots \ldots\end{array}$ & $x$ & & $x$ & & $x$ & \\
\hline \multicolumn{9}{|c|}{ Pair-rule } \\
\hline & paired & Dcitr01g09360.1.1 & $x$ & & $x$ & & & $x$ \\
\hline & odd skipped & Dcitr01g20150.1.1 & $x$ & & $x$ & & & \\
\hline & sloppy paired & Dcitr02g08120.1.1 & $x$ & & $x$ & & & \\
\hline & runt & Dcitr01g07300.1.1 & $x$ & & $x$ & & & $x$ \\
\hline & even-skipped & Dcitro8g10250.1.1 & $x$ & & $x$ & $x$ & & \\
\hline & hairy & Dcitr02g06890.1.1 & $x$ & & $x$ & $x$ & & $x$ \\
\hline & odd paired & Dcitr09g07980.1.1 & $x$ & & $x$ & & & \\
\hline \multicolumn{9}{|c|}{ Segment } \\
\hline & gooseberry & Dcitro1g18500.1.1 & $x$ & & $x$ & $x$ & $x$ & \\
\hline & engrailed & Dcitr08g03480.1.1 & $x$ & & $x$ & & $x$ & \\
\hline
\end{tabular}


bioRxiv preprint doi: https://doi.org/10.1101/2020.12.24.424320; this version posted December 25,2020 . The copyright holder for this preprint (which was not certified by peer review) is the author/funder, who has granted bioRxiv a license to display the preprint in perpetuity. It is made available under aCC-BY-NC 4.0 International license.

\begin{tabular}{|c|c|c|c|c|c|c|c|c|}
\hline \multicolumn{9}{|l|}{ Other } \\
\hline & Runt related $A$ & Dcitro1g07290.1.1 & $x$ & & $\mathrm{x}$ & & & $x$ \\
\hline & Runt related $B$ & Dcitr01g07260.1.1 & $x$ & & $x$ & & & $x$ \\
\hline & lozenge & Dcitro1g07310.1.1 & & $x$ & & $x$ & & $x$ \\
\hline & sister of odd and bowl & Dcitro1g20160.1.1 & $x$ & & $x$ & & & \\
\hline & $\begin{array}{l}\text { brother of odd with } \\
\text { entrails limited }\end{array}$ & Dcitro1g11160.1.1 & $x$ & & & $x$ & & \\
\hline & gooseberry neuro & Dcitr01g18520.1.1 & $\mathrm{x}$ & & $x$ & $x$ & $\mathrm{x}$ & $x$ \\
\hline
\end{tabular}

Table 1. Each manually annotated gene has been assigned an OGS3 gene identifier and denoted as a partial or complete model. Evidence used for manual annotation was also recorded. MCOT [13] and IsoSeq [11] indicate use of these genome-independent transcriptomes to validate the annotation. RNASeq indicates use of mapped RNASeq reads, while orthologs indicates comparison to related proteins was essential for the annotation. Additional information on specific evidence types is included in [12]. ??denotes genes that were complete in OGS2 but are partial in OGS3.

Segmentation gene ortholog number

\begin{tabular}{|c|c|c|c|c|c|c|}
\hline $\begin{array}{l}\text { Maternal } \\
\text { Effect }\end{array}$ & & $\begin{array}{l}\text { Drosophila } \\
\text { melanogaster }\end{array}$ & Apis mellifera & $\begin{array}{l}\text { Tribolium } \\
\text { castaneum }\end{array}$ & $\begin{array}{l}\text { Acyrthosiphon } \\
\text { pisum }\end{array}$ & $\begin{array}{l}\text { Diaphorina } \\
\text { citri }\end{array}$ \\
\hline & caudal & 1 & 1 & 1 & 1 & 1 \\
\hline & $\begin{array}{l}\text { dorsal family } \\
\text { (dorsal, Dorsal-related immunity } \\
\text { factor) }\end{array}$ & 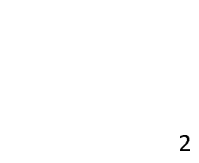 & 1 & 2 & 2 & 1 \\
\hline & nanos & 1 & 1 & 1 & 4 & 1 \\
\hline & bicoid & 1 & 0 & 0 & 0 & 0 \\
\hline & oskar & 1 & 0 & 0 & 0 & 0 \\
\hline & $\begin{array}{l}\text { TGFa ligand } \\
\text { (gurken, Keren, spitz) }\end{array}$ & 3 & 1 & 1 & 1 & 1 \\
\hline Gap & & $\begin{array}{l}\text { Drosophila } \\
\text { melanogaster }\end{array}$ & Apis mellifera & $\begin{array}{l}\text { Tribolium } \\
\text { castaneum }\end{array}$ & $\begin{array}{l}\text { Acyrthosiphon } \\
\text { pisum }\end{array}$ & $\begin{array}{l}\text { Diaphorina } \\
\text { citri }\end{array}$ \\
\hline & tailless & 1 & 1 & 1 & 1 & 1 \\
\hline & $\begin{array}{l}\text { knirps family } \\
\text { (knirps, knirps-like, eagle) }\end{array}$ & 3 & 3 & 2 & 3 & 2 \\
\hline & giant & 1 & 1 & 1 & 0 & 0 \\
\hline & Kruppel & 1 & 1 & 1 & 1 & 1 \\
\hline
\end{tabular}




\begin{tabular}{|c|c|c|c|c|c|c|}
\hline & hunchback & 1 & 1 & 1 & 1 & 1 \\
\hline & huckebein & 1 & 1 & 1 & 0 & 1 \\
\hline & orthodenticle & 1 & 2 & 2 & 1 & 1 \\
\hline & buttonhead & 1 & 1 & 1 & 0 & 0 \\
\hline & empty spiracles & 1 & 1 & 1 & 1 & 1 \\
\hline & cap-n-collar & 1 & 1 & 1 & 1 & 1 \\
\hline & collier & 1 & 1 & 1 & 1 & 1 \\
\hline Pair-rule & & $\begin{array}{l}\text { Drosophila } \\
\text { melanogaster }\end{array}$ & Apis mellifera & $\begin{array}{l}\text { Tribolium } \\
\text { castaneum }\end{array}$ & $\begin{array}{l}\text { Acyrthosiphon } \\
\text { pisum }\end{array}$ & $\begin{array}{l}\text { Diaphorina } \\
\text { citri }\end{array}$ \\
\hline & paired & 1 & 1 & 1 & 1 & 1 \\
\hline & odd skipped & 1 & 1 & 1 & 1 & 1 \\
\hline & sloppy paired 1 /sloppy paired 2 & 2 & 1 & 1 & 1 & 1 \\
\hline & runt & 1 & 1 & 1 & 1 & 1 \\
\hline & even skipped & 1 & 1 & 1 & 1 & 1 \\
\hline & hairy & 1 & 1 & 1 & 1 & 1 \\
\hline & odd paired & 1 & 1 & 1 & 1 & 1 \\
\hline $\begin{array}{l}\text { Segment } \\
\text { polarity }\end{array}$ & & $\begin{array}{l}\text { Drosophila } \\
\text { melanogaster }\end{array}$ & Apis mellifera & $\begin{array}{l}\text { Tribolium } \\
\text { castaneum }\end{array}$ & $\begin{array}{l}\text { Acyrthosiphon } \\
\text { pisum }\end{array}$ & $\begin{array}{l}\text { Diaphorina } \\
\text { citri }\end{array}$ \\
\hline & gooseberry & 1 & 1 & 1 & 1 & 1 \\
\hline & $\begin{array}{l}\text { engrailed family } \\
\text { (engrailed, invected) }\end{array}$ & 2 & 2 & 2 & 2 & 1 \\
\hline
\end{tabular}

Table 2. The Drosophila melanogaster numbers were determined from Flybase. Ortholog numbers for Apis mellifera [18], Tribolium castaneum [40] and Acyrthosiphon pisum [17] are based on genome publications or NCBI. Diaphorina citri ortholog numbers represent our final manual annotation.

\section{Maternal effect genes}

One-to-one orthologs of caudal (cad), dorsal (dl), and nanos (nos) were found in the D. citri v3 genome. $d l$ was previously annotated in the $D$. citri genome v1.1 because of its role in innate immunity [13]. Here we annotated a second isoform of $d l$ (Table 1).

We also identified a single TGF- $\alpha$ ligand-encoding gene in D. citri. In Drosophila, there are three TGF- $\alpha$ ligand paralogs ( $g r k, K r n, s p i)$, but in many other insects, only one TGF- $\alpha$ ligand has been identified [14-18]. Orthologs for bicoid (bcd) and oskar (osk) were not found in $D$. 
citri (Table 2), which is consistent with the previously described phylogenetic distribution of these genes [19].

\section{Gapgenes}

One-to-one orthologs of the gap genes tailless (tIl), Kruppel (Kr), hunchback ( $h b)$ huckebein (hkb), empty spiracles (ems), cap-n-collar ( $c n c)$, and collier (col) were identified and annotated in the D. citri $\mathrm{v} 3$ genome (Tables 1-2). Except for $h k b$, which was reported missing in A. pisum [17], conservation of these genes was expected (Table 2). Two knirps-related (knrl) genes and two orthodenticle (otd) homologs were annotated and are discussed in more detail below. giant ( $g t)$ and buttonhead (btd) appear to be absent in the v3 $D$. citri genome assembly (Table 2).

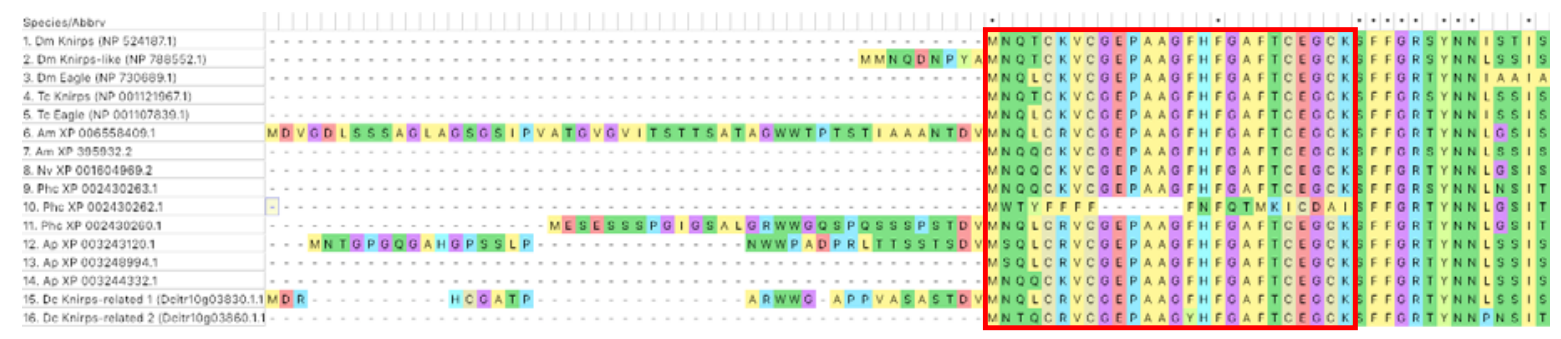

Figure 1. Multiple alignment of the N-terminal region of Knirps family proteins. The red box denotes the sequence encoded by a highly conserved exon [20]. Species represented are Drosophila melanogaster (Dm), Tribolium castaneum (Tc), Apis mellifera (Am), Nasonia vitripennis (Nv), Pediculus humanus (Ph), Acyrthosiphon pisum (Ap) and Diaphorina citri (Dc). Named proteins have been manually annotated, while those with only an accession number are computationally predicted. Five of the knirps family genes (one each in Dm, Am, Ph, Ap and Dc) have sequence upstream of the universally conserved sequence that typically begins in the first exon [ 20 and this work]. In these proteins the conserved core sequence (red box) begins in the second exon. Four of the five proteins with an additional 5 ' exon (Am, Ph, Ap and Dc) share a small region of sequence identity at the C-terminal end of the sequence encoded by this exon. 
Phylogenetics of the knirps family suggests that a single ancestral gene duplicated early in the insect lineage producing two paralogs that have been called knirps-related (knrl) and eagle (eg) [20]. Subsequent duplications have occurred in various insect lineages. A duplication in the lineage leading to Drosophila resulted in the paralogs knirps and knirpslike (also called knirps-related) [20]. A separate duplication of $k n r l$ seems to have occurred in the hemipteroid lineage leading to three knirps family genes (two knrl and one eg) in most hemipterans [20]. However, in the $D$. citri genome v3 we were only able to identify two knirps family genes (Tables 1-2), one of which was annotated as knirps in D. citri genome v1.1 [13]. The two knirps family genes are located on the same chromosome, about $400 \mathrm{~kb}$ apart. Both predicted proteins contain the highly conserved 94 amino acid $\mathrm{N}$ terminal domain and the C terminal PIDLS motif commonly found in knirps family members [20]. However, neither contains the GASS-domain motif that is unique to the Eg protein [20]. Due to the lack of this signature Eagle motif, the resulting $D$. citri annotations were named knirps related $1(k n r l 1)$ and knirps related $2(k n r l 2)$. Despite the lack of the GASS-domain, it is possible that $D$. citri $k n r l 2$ is the ortholog of eg since phylogenetic analysis was inconclusive (data not shown). Interestingly, D. citri knrl1 has a small exon just 5' of the highly conserved coding exon that is the first exon in most knirps family genes (Figure 1). Similar gene structure has been reported for one knirps family gene each in D. melanogaster, the honeybee Apis mellifera, A. pisum, and the human louse Pediculus [20]. All but $D$. melanogaster share small stretches of sequence identity in the amino acid sequence encoded by this additional exon, suggesting that the $5^{\prime}$ exon might have been present in a common ancestor. This model suggests a duplication and acquisition of an additional exon by one paralog early in the insect lineage. The paralog containing the additional exon 
appears to have been lost sometime after the divergence of the Hymenoptera from the rest of the Holometabola.

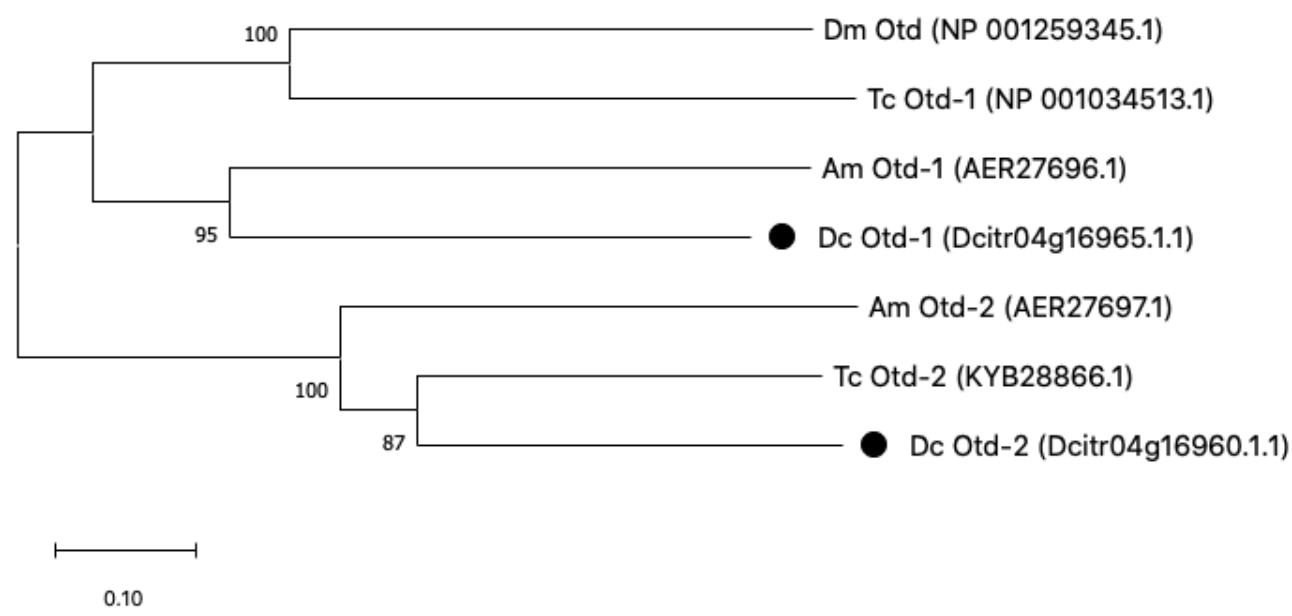

Figure 2. Neighbor joining tree of Otd homologs from Drosophila melanogaster (Dm), Tribolium castaneum (Tc), Apis mellifera (Am), and Diaphorina citri (Dc). D. citri proteins are marked with black circles.

Most insects have two otd genes. However, in both Drosophila and A. pisum only one otd gene has been identified. Drosophila is missing the otd-2 ortholog, while otd-1 has apparently been lost in pea aphids [21]. In the D. citri v3 genome, we found two otd genes adjacent to one another on chromosome 4 (Table 1). Phylogenetic analysis suggests that one of these genes is an otd-1 ortholog, while the other is an otd-2 ortholog (Figure 2). otd1 and otd-2 are also clustered in other insects and crustaceans where their genomic location has been examined [22], suggesting that there are probably evolutionary constraints preventing their separation.

$g t$ is conserved in some, but not all, hemipterans. A gt ortholog was not found in the $A$. pisum genome [17], however, apparent gt orthologs are present in Rhodnius prolixus, Cimex 
lectularius, Halyomorpha halys, Oncopeltus fasciatus and Bemisia tabaci [23-27]. RNAi

studies indicate that the $R$. prolixus and $O$. fasciatus gt orthologs both function as gap genes

$[23,26]$. We performed BLAST searches of $D$. citri genome v3 with all of these hemipteran

Gt orthologs, but were unable to identify a D. citrigt ortholog (Table 2).

btd is a member of the Sp-family of transcription factors. Recent reports indicate that presence of three Sp members is likely the ancestral state for arthropods and perhaps all metazoans [28]. These three Sp-family genes cluster into three monophyletic clades (Sp5/btd, Sp1-4/ (Sp-pps) and Sp6-9 (Sp1)) [28]. Despite the fact that three Sp-family members appears to be the ancestral state, btd is absent from the A. pisum genome [17] and repeated efforts to clone btd from Oncopeltus fasciatus has only resulted in the identification of the two non btd Sp genes, suggesting that btd may have been lost in the lineage leading to hemipterans. We too were unable to find a true btd ortholog in either the D. citri genome $\mathrm{v} 3$ or in independent de novo transcriptomes (Table 2), but we did find two Sp-family members that appear to be orthologous to Sp1 and Spps.

\section{$\underline{\text { Pair-rule genes }}$}

One-to-one orthologs were found for all pair-rule genes examined, including paired ( $p r d)$, odd skipped (odd), sloppy paired (slp), runt (run), even skipped (eve), hairy ( $h$ ) and odd paired (opa) in the D. citri genome v3 (Tables 1-2). A partial copy of $h$ had been annotated in a previous genome version [13]. Three of the pair-rule genes we annotated have closely related paralogs and required additional analysis before gene identities could be assigned. 
Prd is a member of the Pax3/7 family of proteins. In Drosophila there are three Pax3/7 family genes which are known to play a role in segmentation and neurogenesis, prd, gooseberry (gsb) and gooseberry-neuro (gsb-n). While the number of Pax3/7 genes varies in arthropods, data from insects and arachnids suggest that the Pax3/7 roles in segmentation and neurogenesis are likely to be conserved in all arthropods [29]. In the D. citri genome v3 we also found three Pax3/7 genes that we named D.citri_paired, D. citri_gooseberry and $D$. citri_gooseberry-neuro based on reciprocal BLAST analysis and genomic location (Tables 12). The $g s b$ and $g s b-n$ orthologs are discussed in more detail in the segment polarity gene section.

odd is a zinc finger transcription factor that has three close relatives known as brother of odd with entrails limited (bowl), sister of odd and bowl (sob) and drumstick (drum). All four genes are located in an evolutionarily conserved cluster [30]. In D. citri genome v3, drum, odd and sob are all located within $400 \mathrm{~kb}$, with odd and sob overlapping one another on opposite strands. It's not clear whether the overlap is correct or results from misassembly, but the genes are almost certainly located very close together. D.citri bowl is located on the same chromosome about $20 \mathrm{Mb}$ away. Separation of bowl from the rest of the cluster has also been observed in Anopheles gambiae [31].

There are four runt domain-containing genes in insects: run, Runt related $A$ (RunxA), Runt related $B($ Run $x B)$ and lozenge $(I z)$. All four genes are typically found in a cluster and their order and orientation is well conserved across insects [18] (Figure 3). We were able to annotate full length models for all four genes in the $D$. citri genome. It appears that the 
cluster is intact, with all four RDP genes identified in their expected order within a $300 \mathrm{~kb}$ region (Figure 3).

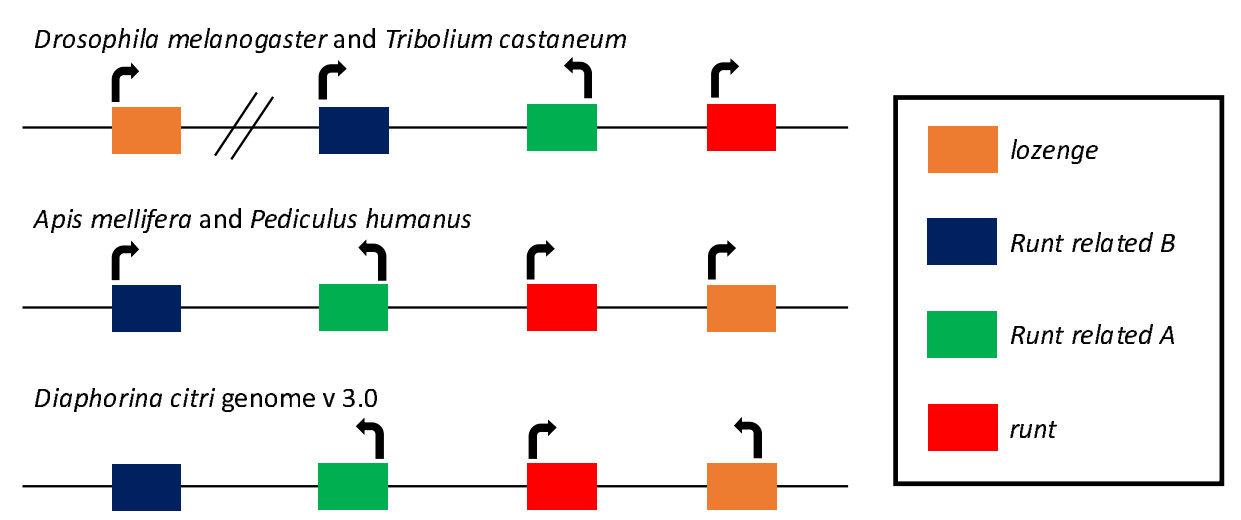

Figure 3. Runt Domain (RD) cluster in representative insects. Cluster information from other insects was obtained from [48]. The RD clusters in D. melanogaster and T. castaneum have three genes in a core cluster, with lozenge $(\mathrm{Iz})$ separated from the cluster, but on the same chromosome distal to runt (run). The RD clusters in A. mellifera and P. humanus have all four genes clustered together with lz proximal to run. The RD cluster in D. citri most closely follows the pattern seen in A. mellifera and P. humanus. D. citri Iz appears to be transcribed in the opposite direction compared to other insects, but it is possible that this is due to local misassembly. The orientation of $D$. citri Runt related $B($ Runx $B)$ is uncertain, since there are tandem artifactual duplicates that are on opposite strands. We chose the RunxB copy closest to Runt related A (RunxA) for annotation. Future assembly improvements may help resolve the gene orientation in this cluster.

\section{Segment polarity genes}

Many segment polarity genes are members of the Wnt and Hedgehog signaling pathways.

The manual annotation of the Wnt pathway genes in the $D$. citri genome $v 3$ is described in a separate report [32]. Here we report the manual annotation of the segment polarity genes gooseberry (gsb) and engrailed (en) (Table 1). gsb and en each have a tightly linked paralog in many insects [33-35]. Surprisingly, we were unable to find the en paralog invected (inv) in the current genome assembly or the de novo transcriptome. We did find and annotate the gsb paralog gooseberry-neuro $(g s b-n)$ in its expected position adjacent to gsb (Table 1$)$. This 
positional information helped verify the identity of $g s b-n$, since phylogenetic analysis was inconclusive.

\section{Conclusion}

We searched for orthologs of 33 Drosophila segmentation genes in the $D$. citri v3 genome and identified and annotated 24 homologous genes. We were unable to find orthologs for 10 of the Drosophila genes, while $D$. citri has one segmentation gene (otd-2) whose ortholog has been lost in Drosophila. Most of these absences, except eagle and invected, were expected based on the known phylogenetic distribution of the genes. While all the genes discussed in this report were initially identified because of their role in embryonic patterning and segmentation in Drosophila, many of them also have other important functions such as pole cell development, neural stem cell maintenance, sex determination, and immune function. Analysis of expression patterns and gene function will be required to determine which of these genes are involved in D. citri segmentation, and which might be good targets for control of D. citri and Huanglongbing.

\section{Methods}

Segmentation gene orthologs in D. citri genome v3 [11] were identified by BLAST search and confirmed by reciprocal BLAST. Manual annotation was performed in Apollo 2.1.0 [36] using available evidence, such as RNA-Seq reads, IsoSeq transcripts and de novo-assembled transcripts. Multiple alignments were performed with MUSCLE [37] or MEGA7 [38] and phylogenetic analysis was done in MEGA7 or MEGA X [39]. A list of orthologs used in these 
bioRxiv preprint doi: https://doi.org/10.1101/2020.12.24.424320: this version posted December 25. 2020. The copvriaht holder for this preprint (which was not certified by peer review) is the author/funder, who has granted bioRxiv a license to display the preprint in perpetuity. It is made available under aCC-BY-NC 4.0 International license.

analyses can be found in Table 3. More details of the annotation process are described in

[12].

Orthologs used in Alignments and Phylogenetic Analysis

\begin{tabular}{|c|c|c|c|c|}
\hline Species & Accession & Name in NCBI & Name in Tree & References \\
\hline $\begin{array}{l}\text { Drosophila } \\
\text { melanogaster }\end{array}$ & NP_524187.1 & knirps, isoform $A$ & Dm Knirps & {$[20,41]$} \\
\hline $\begin{array}{l}\text { Drosophila } \\
\text { melanogaster }\end{array}$ & NP_788552.1 & $\begin{array}{l}\text { knirps-like, isoform } \\
\text { A }\end{array}$ & Dm Knirps-like & {$[20,41]$} \\
\hline $\begin{array}{l}\text { Drosophila } \\
\text { melanogaster }\end{array}$ & NP_730689.1 & eagle, isoform $B$ & Dm Eagle & {$[20,41]$} \\
\hline $\begin{array}{l}\text { Tribolium } \\
\text { castaneum }\end{array}$ & NP_001121967.1 & knirps & Tc Knirps & {$[40,42]$} \\
\hline $\begin{array}{l}\text { Tribolium } \\
\text { castaneum }\end{array}$ & NP_001107839.1 & eagle & Tc Eagle & {$[40,43]$} \\
\hline Apis mellifera & XP_006558409.1 & $\begin{array}{l}\text { nuclear receptor } \\
\text { subfamily } 1 \text { group D } \\
\text { member } 2 \text { isoform }\end{array}$ & Am XP_006558409.1 & \\
\hline Apis mellifera & XP_006559124.1 & $\begin{array}{l}\text { knirps-related } \\
\text { protein }\end{array}$ & Am XP_395932.2 & \\
\hline Nasonia vitripennis & XP_001604969.2 & $\begin{array}{l}\text { protein embryonic } \\
\text { gonad }\end{array}$ & Nv XP_001604969.2 & \\
\hline $\begin{array}{l}\text { Pediculus humanus } \\
\text { corporis }\end{array}$ & XP_002430263.1 & $\begin{array}{l}\text { conserved } \\
\text { hypothetical protein }\end{array}$ & Phc XP_002430263.1 & \\
\hline $\begin{array}{l}\text { Pediculus humanus } \\
\text { corporis }\end{array}$ & XP_002430262.1 & $\begin{array}{l}\text { conserved } \\
\text { hypothetical protein }\end{array}$ & Phc XP_002430262.1 & \\
\hline $\begin{array}{l}\text { Pediculus humanus } \\
\text { corporis }\end{array}$ & XP_002430260.1 & $\begin{array}{l}\text { knirps related } \\
\text { protein, putative }\end{array}$ & Phc XP_002430260.1 & \\
\hline $\begin{array}{l}\text { Acyrthosiphon } \\
\text { pisum }\end{array}$ & XP_003243120.1 & $\begin{array}{l}\text { knirps-related } \\
\text { protein-like }\end{array}$ & Ap XP_003243120.1 & \\
\hline $\begin{array}{l}\text { Acyrthosiphon } \\
\text { pisum }\end{array}$ & XP_003248994.1 & $\begin{array}{l}\text { protein embryonic } \\
\text { gonad-like }\end{array}$ & Ap XP_003248994.1 & \\
\hline $\begin{array}{l}\text { Acyrthosiphon } \\
\text { pisum }\end{array}$ & XP_003244332.1 & protein doublesex* & Ap XP_003244332.1 & \\
\hline $\begin{array}{l}\text { Drosophila } \\
\text { melanogaster }\end{array}$ & NP_001259345.1 & ocelliless, isoform G & Dm Otd & \\
\hline $\begin{array}{l}\text { Tribolium } \\
\text { castaneum }\end{array}$ & NP_001034513.1 & orthodenticle-1 & Tc Otd-1 & \\
\hline $\begin{array}{l}\text { Tribolium } \\
\text { castaneum }\end{array}$ & KYB28866.1 & orthodenticle-2 & Tc Otd-2 & \\
\hline Apis mellifera & AER27696.1 & orthodenticle 1 & Am Otd-1 & \\
\hline Apis mellifera & AER27697.1 & orthodenticle 2 & Am Otd-2 & \\
\hline
\end{tabular}


Table 3. Species, accession number, full name and abbreviated name are provided for all orthologs used multiple alignments and phylogenetic trees [20,40-47]. Gene names from NCBI that are marked with an asterisk (*) appear to be incorrect annotations.

\section{Acknowledgements}

We thank Will Tank for technical assistance and helpful discussions. This work was supported by USDA-NIFA grant 2015-70016-23028, 2020-70029-33199 and HSI 1300394 in addition to an Institutional Development Award (IDeA) from the National Institute of General Medical Sciences of the National Institutes of Health under grant number P20GM103418.

\section{Author Contributions}

\begin{tabular}{|l|l|}
\hline Conceptualization & W.B.H., S.JB., T.D., L.M. \\
\hline Supervision & T.D.S, S.J.B., T.D, S.S \\
\hline Project Administration & S.J.B., T.D, S.S, L.M \\
\hline Investigation & S.M., T.D.S. \\
\hline Software & P.H., M.F-G, S.S. \\
\hline Methodology & P.H., M.F-G, S.S., T.D.S \\
\hline Funding Acquisition & S.J.B., T.D., W.B.H., L.M. \\
\hline Writing - Original Draft Preparation & S.M., T.D.S \\
\hline Writing - Review and Editing & S.J.B., S.S. \\
\hline
\end{tabular}

\section{References}

1. Nüsslein-volhard C, Wieschaus E. Mutations affecting segment number and polarity in drosophila. Nature. 1980; doi:10.1038/287795a0.

2. Jürgens $G$, Wieschaus $E$, Nüsslein-Volhard $C$, Kluding H. Mutations affecting the pattern of the larval cuticle in Drosophila melanogaster - II. Zygotic loci on the third chromosome.

Wilhelm Roux's Arch Dev Biol. 1984;193:283-95. 
3. Wieschaus $E$, Nüsslein-Volhard $C$, Jürgens $G$. Mutations affecting the pattern of the larval cuticle in Drosophila melanogaster - III. Zygotic loci on the X-chromosome and fourth chromosome. Wilhelm Roux's Arch Dev Biol. 1984;193:296-307.

4. Nüsslein-Volhard C, Wieschaus E, Kluding H. Mutations affecting the pattern of the larval cuticle in Drosophila melanogaster - I. Zygotic loci on the second chromosome. Wilhelm Roux's Arch Dev Biol. 1984;193:267-82.

5. Wieschaus E, Nüsslein-Volhard C. The Heidelberg Screen for Pattern Mutants of Drosophila: A Personal Account. Annu. Rev. Cell Dev. Biol. 2016;32:1-46.

6. Clark E, Peel AD, Akam M. Arthropod segmentation. Dev. Company of Biologists Ltd; 2019; doi:10.1242/dev.170480

7. Hernandez J, Pick L, Reding K. Oncopeltus-like gene expression patterns in Murgantia histrionica, a new hemipteran model system, suggest ancient regulatory network divergence. Evodevo. 2020;11.

8. Reding K, Chen M, Lu Y, Cheatle Jarvela AM, Pick L. Shifting roles of Drosophila pair-rule gene orthologs: segmental expression and function in the milkweed bug Oncopeltus fasciatus. Development. 2019;146.

9. Auman T, Chipman AD. Growth zone segmentation in the milkweed bug Oncopeltus fasciatus sheds light on the evolution of insect segmentation. BMC Evol Biol. 2018;18. 10. Peel AD, Chipman AD, Akam M. Arthropod segmentation: Beyond the Drosophila paradigm. Nat. Rev. Genet. 2005;6:905-16.

11. Hosmani P, Flores-Gonzalez M, Shippy T, Vosburg C, Massimino C, Tank W, et al. Chromosomal length reference assembly for Diaphorina citri using single-molecule sequencing and $\mathrm{Hi}-\mathrm{C}$ proximity ligation with manually curated genes in developmental, structural and immune pathways. bioRxiv. 2019; doi:10.1101/869685 
12. Shippy, TD; Miller, S; Massimino, C; Vosburg, C; Hosmani, PS; Flores-Gonzalez, M;

Mueller, LA; Hunter, WB; Benoit, JB; Brown, SJ; D’elia, T; Saha S. Annotating genes in

Diaphorina citri genome version 3. protocols.io. 2020; doi: 10.17504/protocols.io.bniimcce

13. Saha S, Hosmani PS, Villalobos-Ayala K, Miller S, Shippy T, Flores M, et al. Improved annotation of the insect vector of citrus greening disease: biocuration by a diverse genomics community. Database (Oxford). 2017; doi:10.1093/database/bax032

14. Stein RA, Staros J V. Insights into the evolution of the ErbB receptor family and their ligands from sequence analysis. BMC Evol Biol. 2006;6.

15. Werren JH, Richards S, Desjardins CA, Niehuis O, Gadau J, Colbourne JK, et al. Functional and evolutionary insights from the genomes of three parasitoid nasonia species. Science. $2010 ; 327: 343-8$.

16. Richards S, Gibbs RA, Weinstock GM, Brown SJ, Denell R, Beeman RW, et al. The genome of the model beetle and pest Tribolium castaneum. Nature. 2008;452.

17. Shigenobu S, Bickel RD, Brisson JA, Butts T, Chang C, Christiaens O, et al. Comprehensive survey of developmental genes in the pea aphid, Acyrthosiphon pisum: frequent lineagespecific duplications and losses of developmental genes. Insect Mol Biol. 2010;19:47-62.

18. Dearden PK, Wilson MJ, Sablan L, Osborne PW, Havler M, McNaughton E, et al. Patterns of conservation and change in honey bee developmental genes. Genome Res.

$2006 ; 16: 1376-84$.

19. Rosenberg MI, Lynch JA, Desplan C. Heads and tails: Evolution of antero-posterior patterning in insects. Biochim. Biophys. Acta. 2009;1789:333-42.

20. Naggan Perl T, Schmid BGM, Schwirz J, Chipman AD. The evolution of the knirps family of transcription factors in arthropods. Mol Biol Evol. 2013;30:1348-57.

21. Huang T-Y, Cook CE, Davis GK, Shigenobu S, Chen RP-Y, Chang C-C. Anterior development 
in the parthenogenetic and viviparous form of the pea aphid, Acyrthosiphon pisum:

hunchback and orthodenticle expression. Insect Mol Biol. 2010;19 Suppl 2:75-85.

22. Browne WE, Schmid BGM, Wimmer EA, Martindale MQ. Expression of otd orthologs in the amphipod crustacean, Parhyale hawaiensis. Dev Genes Evol. 2006;216:581-95.

23. Lavore A, Pagola L, Esponda-Behrens N, Rivera-Pomar R. The gap gene giant of Rhodnius prolixus is maternally expressed and required for proper head and abdomen formation. Dev Biol. 2012;361:147-55.

24. Benoit JB, Adelman ZN, Reinhardt K, Dolan A, Poelchau M, Jennings EC, et al. Unique features of a global human ectoparasite identified through sequencing of the bed bug genome. Nat Commun. 2016;7.

25. Sparks ME, Bansal R, Benoit JB, Blackburn MB, Chao H, Chen M, et al. Brown marmorated stink bug, Halyomorpha halys (Stål), genome: Putative underpinnings of polyphagy, insecticide resistance potential and biology of a top world wide pest. BMC Genomics. 2020;21.

26. Liu PZ, Patel NH. Giant is a bona fide gap gene in the intermediate germband insect, Oncopeltus fasciatus. Development. 2010;137:835-44.

27. Chen W, Hasegawa DK, Kaur N, Kliot A, Pinheiro PV, Luan J, et al. The draft genome of whitefly Bemisia tabaci MEAM1, a global crop pest, provides novel insights into virus transmission, host adaptation, and insecticide resistance. BMC Biol. 2016;14.

28. Schaeper ND, Prpic N-M, Wimmer EA. A clustered set of three Sp-family genes is ancestral in the Metazoa: evidence from sequence analysis, protein domain structure, developmental expression patterns and chromosomal location. BMC Evol Biol. 2010;10:88. 29. Davis GK, D'Alessio JA, Patel NH. Pax3/7 genes reveal conservation and divergence in the arthropod segmentation hierarchy. Dev Biol. 2005;285:169-84. 
30. Linz DM, Tomoyasu Y. RNAi screening of developmental toolkit genes: a search for novel wing genes in the red flour beetle, Tribolium castaneum. Dev Genes Evol. 2015;225:11-22.

31. Johansen KA, Green RB, Iwaki DD, Hernandez JB, Lengyel JA. The Drm-Bowl-Lin relief-ofrepression hierarchy controls fore- and hindgut patterning and morphogenesis. Mech Dev. $2003 ; 120: 1139-51$.

32. Vosburg C, Reynolds M, Noel R, Shippy T, Hosmani PS, Flores-Gonzalez M, et al. Characterization of Wnt Signaling Genes in Diaphorina citri. bioRxiv. 2020; doi:10.1101/2020.09.21.306100

33. Peel AD, Telford MJ, Akam M. The evolution of hexapod engrailed-family genes: evidence for conservation and concerted evolution. Proceedings Biol Sci. 2006;273:1733-42. 34. Bopp D, Burri M, Baumgartner S, Frigerio G, Noll M. Conservation of a large protein domain in the segmentation gene paired and in functionally related genes of Drosophila. Cell. 1986;47:1033-40.

35 Osborne PW, Dearden PK. Expression of Pax group III genes in the honeybee (Apis mellifera). Dev Genes Evol. 2005;215:499-508.

36. Dunn NA, Unni DR, Diesh C, Munoz-Torres M, Harris NL, Yao E, et al. Apollo: Democratizing genome annotation. PLOS Comput Biol. 2019;15:e1006790.

37. MUSCLE. 2020 https://www.ebi.ac.uk/Tools/msa/muscle/ Accessed 26 Oct 2020.

38. Kumar S, Stecher G, Tamura K. MEGA7: Molecular Evolutionary Genetics Analysis Version 7.0 for Bigger Datasets. Mol Biol Evol. 2016;33:1870-4.

39. Kumar S, Stecher G, Li M, Knyaz C, Tamura K. MEGA X: Molecular evolutionary genetics analysis across computing platforms. Mol Biol Evol. 2018;35:1547-9.

40. Tribolium Genome Sequencing Consortium, Richards S, Gibbs RA, Weinstock GM, Brown SJ, Denell R, et al. The genome of the model beetle and pest Tribolium castaneum. Nature. 
2008;452:949-55.

41. Adams MD, Celniker SE, Holt RA, Evans CA, Gocayne JD, Amanatides PG, et al. The genome sequence of Drosophila melanogaster. Science. 2000;2185-95.

42. Cerny AC, Grossmann D, Bucher G, Klingler M. The Tribolium ortholog of knirps and knirps-related is crucial for head segmentation but plays a minor role during abdominal patterning. Dev Biol. 2008;321:284-94.

43. Bucher G, Farzana L, Brown SJ, Klingler M. Anterior localization of maternal mRNAs in a short germ insect lacking bicoid. Evol Dev. 2005;7:142-9.

44. Elsik CG, Worley KC, Bennett AK, Beye M, Camara F, Childers CP, et al.. Finding the missing honey bee genes: lessons learned from a genome upgrade. BMC Genomics. 2014; doi: 10.1186/1471-2164-15-86.

45. Werren JH, Richards S, Desjardins CA, Niehuis O, Gadau J, Colbourne JK, et al.. Functional and evolutionary insights from the genomes of three parasitoid Nasonia species. Science. 2010; doi: 10.1126/science.1178028.

46. Kirkness EF, Haas BJ, Sun W, Braig HR, Perotti MA, Clark JM, et al. Genome sequences of the human body louse and its primary endosymbiont provide insights into the permanent parasitic lifestyle. Proc Natl Acad Sci U S A. 2010; doi:10.1073/pnas.1003379107 47. International Aphid Genomics Consortium. Genome sequence of the pea aphid Acyrthosiphon pisum. PLoS Biol. 2010; doi: 10.1371/journal.pbio.1000313.

48. Duncan EJ, Wilson MJ, Smith JM, Dearden PK. Evolutionary origin and genomic organisation of runt-domain containing genes in arthropods. BMC Genomics. 2008;9:558. 